Article

\title{
Eating Disorder Symptoms and Body Image in Adolescents from Public Schools in Brazil
}

Roges Ghidini Dias ${ }^{1 *}$, Ricardo Rodrigo Rech ${ }^{1,2}$ and Ricardo Halpern ${ }^{1}$

1 Federal University of Health Sciences of Porto Alegre; rgepidemio@gmail.com

2 University of Caxias do Sul; rrrech@ucs.br

* Correspondence: rgepidemio@gmail.com

\begin{abstract}
There is growing recognition of the adverse effects of body image dissatisfaction (BID) and eating disorder (ED) symptoms on adolescent health. The aim of this study was to estimate the prevalence of ED symptoms, BID, and their relationship in adolescents from public schools in Southern Brazil. A total of 782 schoolchildren (male: $n=420$, female: $n=362$ ); age: $15 \pm 0,4$ years) answered a self-administrated questionnaire to identify sociodemographic data. Children's Figure Rating Scale was adopted to identify body image and Eating Attitudes Test (EAT-26) was applied to investigate ED symptoms. Inferential statistics and hierarchical model-controlled logistic regression were used for association between variables. Most of the schoolchildren reported being satisfied with their bodies. However, we observed a higher prevalence of dissatisfaction among girls for being overweight and thinness among boys. Female students and students from schools located in the central area of the city showed higher chances of developing ED symptoms, and the absence of symptoms of ED appeared to act as a protective factor against BID in schoolchildren. Results of this study show the need to reflect on these factors that influence the development of ED and non-acceptance of their own body in a population concerned with their physical appearance.
\end{abstract}

Keywords: Obesity; Eating Disorder; Body Image; Adolescents.

\section{Introduction}

Adolescence is recognized as a critical time for establishing lifelong health behaviors [1] and marked by rapid physical, cognitive, social, emotional, and sexual growth and development [2] when there is tremendous concern about physical appearance [3].

During adolescence, the body assumes a prominent place due to several transformations, and the literature points to evidence of a growing fear of body image among adolescents - a phenomenon that has been progressively occurring at earlier ages $[4,5]$. Studies have shown the influence of sociodemographic aspects [6] and gender differences in the development of body image dissatisfaction (BID) [7]. BID is an aspect of body image related to negative evaluations of body size, shape, muscle tone, and weight, and generally involves the distorted perception between a personal evaluation of one's own body and the desire for a body considered ideal [8]. Today the conception of body image is based on a combination of perceptual, affective, and cognitive components with behavioral features. Although the results are somewhat contradictory in reports on adolescent patients, many individuals overestimate their body size in 
comparison with healthy controls. Certain body parts are more overestimated than others, especially the thighs and waist.

Table 1. Comparison of variables of students by gender (n; \%).

\begin{tabular}{|c|c|c|c|c|}
\hline & \multicolumn{4}{|c|}{ Gender } \\
\hline & Variables & $\begin{array}{l}\text { Female } \\
(n=362)\end{array}$ & $\begin{array}{c}\text { Male } \\
(n=420)\end{array}$ & $p$-value \\
\hline \multirow[t]{2}{*}{ Sedentary Habits } & Until $3 \mathrm{~h}$ & $174(48.1 \%)$ & $186(44.5 \%)$ & 0.087 \\
\hline & $>3 \mathrm{~h}$ & $188(51.9 \%)$ & $234(55.5 \%)$ & $0.046^{*}$ \\
\hline PA Out & Yes & $181(50.0 \%)$ & $115(27.4 \%)$ & $0.047^{*}$ \\
\hline of School & No & $181(50.0 \%)$ & $305(72.6 \%)$ & $0.032^{*}$ \\
\hline \multirow[t]{2}{*}{ BMI } & No OW & $94(26.0 \%)$ & $165(39.3 \%)$ & $0.042^{*}$ \\
\hline & With OW & $268(74.0 \%)$ & $255(60.7 \%)$ & 0.053 \\
\hline \multirow[t]{2}{*}{ BID } & Not Satisfied & $224(61.9 \%)$ & $130(31.0 \%)$ & $0.031^{*}$ \\
\hline & Satisfied & $138(38.1 \%)$ & $290(69.0 \%)$ & $0.028^{*}$ \\
\hline \multirow[t]{2}{*}{ BID Type } & Thinness & $94(41.9 \%)$ & $83(63.8 \%)$ & $0.044^{*}$ \\
\hline & Excess & $130(58.1 \%)$ & $47(36.2 \%)$ & $0.034^{*}$ \\
\hline ED & Yes & $249(68.8 \%)$ & $154(40.3 \%)$ & $0.036^{*}$ \\
\hline Symptoms & No & $113(31.2 \%)$ & $266(51.7 \%)$ & $0.032^{*}$ \\
\hline School & Central & $243(67.1 \%)$ & $291(69.3 \%)$ & 0.062 \\
\hline Location & Peripheral & $119(32.9 \%)$ & $129(30.7 \%)$ & 0.074 \\
\hline Maternal & Elementary School & $270(74.6 \%)$ & $319(76.0 \%)$ & 0.071 \\
\hline Education & High School & $92(25.4 \%)$ & $101(24.0 \%)$ & 0.086 \\
\hline
\end{tabular}

BMI: Body Mass Index; OW Overweight; ED: Eating Disorders; BID: Body Image Dissatisfaction; PA: Physical Activities;

* Significant values at $\mathrm{p}<0.05 ;(\mathrm{n}=782)$.

Table 2. Logistic regression between eating disorder symptoms and independent variables.

\begin{tabular}{|c|c|c|c|c|c|c|c|}
\hline \multirow[b]{2}{*}{ Variables } & \multirow[b]{2}{*}{$\beta$} & \multirow[b]{2}{*}{ SE } & \multirow[b]{2}{*}{ Wald } & \multicolumn{3}{|c|}{ CI $(95 \%)$} & \multirow[b]{2}{*}{$p$-value } \\
\hline & & & & OR & Lower & Superior & \\
\hline \multicolumn{8}{|c|}{ Block 1. Control Variables } \\
\hline Gender & -0.82 & 0.30 & 7.449 & 1.44 & 1.24 & 1.79 & $0.006^{*}$ \\
\hline Maternal Education & -0.08 & 0.53 & 0.028 & 0.91 & 0.32 & 2.57 & 0.87 \\
\hline School Location & 0.36 & 0.20 & 3.334 & 1.84 & 1.30 & 2.14 & $0.03^{*}$ \\
\hline \multicolumn{8}{|c|}{ Block 2. Behavioral Variables } \\
\hline Sedentary Habits & 0.13 & 0.26 & 0.251 & 1.14 & 0.68 & 1.91 & 0.61 \\
\hline PA out of School & 0.17 & 0.29 & 0.003 & 1.14 & 0.57 & 1.80 & 0.95 \\
\hline \multicolumn{8}{|c|}{ Block 3. Nutritional Status and BI } \\
\hline BMI & 0.94 & 0.27 & 0.11 & 1.09 & 0.64 & 1.88 & 0.73 \\
\hline BID & 1.76 & 0.46 & 14.634 & 5.83 & 2.36 & 14.4 & $<0.001^{*}$ \\
\hline
\end{tabular}

BMI: Body Mass Index; SE: Standard Error; OR: Odds Ratio; BI: Body Image; CI: Confidence Interval; PA: Physical Activities; BID: Body Image Dissatisfaction; *Significant Values $p(\mathrm{p}<0.05)$. 
Table 3. Logistic regression between Body Image Dissatisfaction and independent variables.

\begin{tabular}{|c|c|c|c|c|c|c|c|}
\hline \multirow[b]{2}{*}{ Variables } & \multirow[b]{2}{*}{$\beta$} & \multirow[b]{2}{*}{ SE } & \multirow[b]{2}{*}{ Wald } & \multicolumn{3}{|c|}{ CI $(95 \%)$} & \multirow[b]{2}{*}{ p-value } \\
\hline & & & & OR & Lower & Superior & \\
\hline \multicolumn{8}{|l|}{ Block 1. Control Variables } \\
\hline Gender & -0.26 & 0.19 & 1.784 & 0.77 & 0.52 & 1.13 & 0.18 \\
\hline Maternal Education & -0.20 & 0.70 & 9.122 & 2.53 & 1.86 & 6.38 & $0.002^{*}$ \\
\hline School Location & -0.09 & 0.29 & 0.099 & 0.91 & 0.51 & 1.61 & 0.75 \\
\hline \multicolumn{8}{|l|}{ Block 2. Behavioral Variables } \\
\hline Sedentary Habits & -0.21 & 0.18 & 1.335 & 0.81 & 0.56 & 1.16 & 0.24 \\
\hline Physical Activities out of School & 0.14 & 0.20 & 0.48 & 1.15 & 0.77 & 1.70 & 0.49 \\
\hline \multicolumn{8}{|l|}{ Block 3. Nutritional Status and ED } \\
\hline BMI & 1.48 & 0.25 & 34.324 & 4.41 & 2.69 & 7.26 & $<0.001^{*}$ \\
\hline ED Symptoms & -0.83 & 0.31 & 7.115 & 0.44 & 0.24 & 0.80 & $0.008^{*}$ \\
\hline
\end{tabular}

The manner adolescents perceive their body image interferes with their social life and mental health [2]. Consequently, the emergence of BID often ends up affecting their development and well-being, leading to self-esteem problems [9], depressive symptoms [10], and unhealthy eating behavior among adolescents [11]. Eating behavior is multifactorial influenced, including social, demographic, and cultural issues [7,12]. During this phase, adolescents typically consume nutrient-poor diets and fail to meet the minimum recommendations for fruit, vegetables, whole grains, and dairy products, but exceed the maximum recommended intake of saturated fat and sugars, sometimes leading to eating disorders [13].

Eating disorders (ED) are unique attitudes related to food and behaviors and include fear of gaining weight, desire to lose weight, insufficient dietary intake, binge eating, self-induced vomiting, and laxative use [14]. Apart from being predictors for the development of obesity in adulthood, these behaviors are harmful and can affect the development of a growing adolescent [14,15]. Eating disorders are the third most common chronic illness among adolescents, after obesity and asthma [15] ; the peak age of onset occurs between 14 and 19 years.

Therefore, the objectives of this study were to identify the prevalence of ED and BID symptoms and investigate how these characteristics are related in a sample of adolescents living in a city in southern Brazil.

\section{Materials and Methods}

\subsection{Sample Size Calculation}


This study is part of a larger project titled, "Obesity, Dissatisfaction with Body Image and Eating Disorders in a Cohort of School Children in Serra Gaucha" [16]. The target population of the study was composed of students aged 14 to 17 years and enrolled in the municipal public school system of Caxias do Sul in 2014 ( $N=3180)$. To calculate the sample size, we used a prevalence of $50 \%$, a confidence interval of $95 \%$, an error of $3 \%$, and a design effect of 1.20, requiring a total of 959 students. Sampling was done by conglomerates, and 22 schools were drawn to complete the minimum number of students to be evaluated. A total of 798 subjects answered the research questionnaire. Sixteen subjects were excluded due to missing data, and 782 students were considered in the final sample.

\subsection{Questionnaire}

A self-administered questionnaire was used to identify socio-demographic data, schoolchildren's age, gender (female or male), the practice of physical activities outside the school environment (yes or no), sedentary habits (up to 3 hours/day or more than 3 hours/day), and maternal education (complete elementary school or high school). There were no respondents with incomplete elementary school education or college education. The questionnaire was designed by the authors and previously tested in a pilot study conducted with 15 children from a school in the city of Caxias do Sul who did not participate in this study.

BID was evaluated by the Children's Figure Rating Scale [17]. The scale contains nine numbered silhouettes, with extremes of thinness and fatness, with stable height, and is presented separately according to gender, with positive values indicating a desire for a smaller body (dissatisfaction by excess) and negative values indicating a desire for a larger body (dissatisfaction by thinness). To collect anthropometric measurements of total body mass and height, a Plenna digital portable scale (accurate to $100 \mathrm{~g}$ ), a wall-mounted stadiometer, and a set square were used. The body mass index (BMI) was identified and classified according to the cut-off points proposed by Conde and Monteiro (2006) [18].

School locations was classified into two categories (central and peripheral area), and schools in the peripheral area were considered to be all those within a radius greater than or equal to two kilometers from the epicenter of the city of Caxias do Sul (coordinates $29^{\circ} 09^{\prime} 48^{\prime \prime}$ South and 5110'46" West). ED was assessed by the Eating Attitudes Test (EAT26) summarized and validated for the Brazilian adolescent population [19]. Those assessed are classified according to the score obtained, so that scores greater than or equal to 21 points are considered symptomatic and below 21 as asymptomatic.

\subsection{Statistical Analysis}

Data were analyzed using the program IBM-SPSS ${ }^{\circledR}$ version 23 using descriptive and inferential statistics. McNemar's test was used to analyze differences between independent variables and logistic regression to verify associations between independent variables and outcomes, controlled by a hierarchical model. The regression analysis was performed in three blocks, being the first block composed by the sociodemographic variables 
(gender, maternal education, and school location area), the second by the behavioral variables (sedentary habits and practice of activities outside school), and the third by the nutritional status (BMI) and the type of dissatisfaction with body image (excess or thinness). The significance level adopted was 5\%. This study was approved by the research ethics committee of the Federal University of Health Sciences of Porto Alegre (UFCSPA) with opinion number 1312/11 and registration 741/11.

\section{Results}

\subsection{Group Characteristics}

A total of 782 participants completed the questionnaire and were included in the analyses for the present study. Mean age of the participants was $15 \pm 0.4$ years. The prevalence of sedentary habits was higher for the more than three hours per day category with significant differences between genders. Although most subjects reported not practicing physical activities outside the school environment ( $n=486 ; 62.1 \%)$, significant differences were observed between genders for both performing $(p=0.032)$ and not performing these activities $(p=0.047)$. Most of the school children were overweight $(n=523$; $66.9 \%$ ), however, significant differences were observed between genders only for school children who were not overweight $(\mathrm{p}=0.042)$.

Although most of the school children reported being satisfied with their bodies $(\mathrm{n}=428 ; 56.2 \%)$, significant differences were observed in the BID evaluation for both genders. A higher prevalence of dissatisfaction for overweight was identified among girls and for thinness for boys, and statistically significant differences were found in the desire for a smaller body ( $p=0.034)$ to girls and for a larger body $(p=0.044)$ among boys. The prevalence of ED symptoms was higher among girls, and statistically significant differences were identified in the comparison between genders for both the presence $(p=0.036)$ and absence of ED symptoms $(p=0.032)$. Most of the participants attend schools located in the central area of the municipality $(n=534 ; 68.3 \%)$ and belong to families whose mothers have completed elementary school $(\mathrm{n}=589 ; 75.3 \%)$. The group characteristics are listed in Table 1.

Insert Table 1 here

Insert Table 2 here

According to table 2, it is possible to identify that the highest chances of developing ED symptoms are associated with the female gender $(\mathrm{OR}=1.44 ; 95 \%$ - CI 1.24 $1.79)$ and BID (OR = 5.83; 95\% - CI 2.36 - 14.4). In addition, students from schools located in the central area of the city seem to be more exposed to this phenomenon $(\mathrm{OR}=1.84 ; 95 \%$ - CI $1.30-2.14)$. Table 3 shows the influence of maternal education $(\mathrm{OR}=2.53 ; 95 \%$ - CI $1.86-6.38)$ and overweight (OR $=4.41 ; 95 \%-\mathrm{CI} 2.69-7.26)$ on the development of BID. The results also show that the absence of ED symptoms seems 
to act as a protective factor for BID (OR $=0.44 ; 95 \%$ - CI $0.24-0.80)$ in schoolchildren. The other predictor variables showed no statistically significant relationship with the outcomes. OR values in tables 2 and 3 are adjusted.

Insert Table 3 here

\section{Discussion}

Adolescence is an important period full of changes, which can be observed in several areas including anatomical, physiological, behavioral, and social, and the transformations resulting from this phase of life reflect on the behavior of adolescents [20]. Adolescents are targets of campaigns that promote the idea of an ideal body, and their vulnerability to an aesthetic standard imposed by the media often results in the search for a physical image that is very different from their own. The prevalence of BID observed in our study (45.3\%), despite differing from the results of some national $[21,22]$ and international $[23,24]$ studies, causes great concern, since it reflects the way adolescents conduct the process of identifying and accepting their body shape.

The prevalence was higher among girls, and these results that are in line with previous studies [24,25]. The differences in prevalence are possibly related to differences in the age groups investigated, the cultural diversity of each region, or the different assessment instruments used across the studies. Some studies provide important data about BID and its associated factors, among which we can mention gender, adolescent stage, socioeconomic conditions, local culture, being overweight, exposure to the media and social networks $[26,27,28]$.

Concern over body image may start at the beginning of adolescence, increase during that period, and diminish in young adults, affecting psychological well-being in different phases of life [24]. The kind and degree of body image disorder varies with age, ethnic group, peers, family, and sociocultural influences. Sociocultural influences have been considered the strongest determining factors for developing a negative body image disorder and a predictor of ED due to acceptance pattern of the thin ideal by adolescents [27]. Previous studies in Brazilian populations reported that adolescents presented BD and BID apparently is associated with it.

Uchôa et. al, [29] reported $28.6 \%$ of the adolescents presented dissatisfaction with their bodies. Cecon et. al, [30] in their study identified that BID increased by more than 13 times the chance of developing ED, being considered a potential risk factor. Alves et. al, [31], investigate Brazilian schoolchildren and found prevalence around 23.0\% of students with ED. In addition, they observed an association between the presence of EF symptoms and BID and the influence of maternal education on body image.

Another factor with a potential effect on the health status of children and adolescents is the level of maternal education. Previous studies have identified positive associations between maternal education and several health events, such as reduced infant mortality [32], maintenance of exclusive breastfeeding [33], and less passive leisure time in front of screens [34]. 
Although there are factors that make it impossible to generalize the statement that the increase in maternal education level acts as a protective factor for health outcomes in the child and adolescent population, it is reasonable to believe that mothers with high educational levels can stimulate their children to develop autonomy and resist social and media pressures for an unhealthy aesthetic standard.

In our study, more than $70 \%$ of the mothers of the adolescents surveyed reported having attended only elementary school. This result reinforces the idea that the educational factor may have contributed to the high number of adolescents dissatisfied with their body image.

The high prevalence of overweight adolescents in our study reflects a common reality in the adolescent population, while at the same time reinforcing an unavoidable concern to undertake greater efforts in prevention and intervention actions for these conditions during childhood and adolescence. Amaral and Ferreira [35] found that aesthetics, self-esteem and health are the main reasons that influenced BID. Overweight teenagers are more likely to become dissatisfied with their body image, and this concern with physical appearance encourages them to seek a beauty pattern linked to an overvaluation of a thin body. They may feel particularly vulnerable and tend lower participation in physical activity programs, and, consequently, more sedentary behavior compared to normal weight teenagers, increasing their vulnerability in a vicious circle between overweight and BID.

Most adolescents in this study overestimate their body size or overvalue their weight or body shape, which directly interferes with their self-esteem. This finding reflects the internalization of a belief process a tool for acceptance and insertion of adolescents in social groups, thus adopting the belief promoted in Western society that thin subjects are more desirable [36]. The diffusion of thinness and the overvaluation of weight are major contributors to the high prevalence of fear of gaining weight, excessive weight control, and unhealthy behaviors [37]; a phenomenon referred to in the literature as "normative dissatisfaction" [38], which is associated with the influence of mass media [29]. The degree of body dissatisfaction is usually high in the obese population, and inadequate nutritional status and body adiposity are determining factors for the increase of this dissatisfaction $[39,40,41]$.

ED are pathological conditions that characterize a distorted relationship between the individual, his eating behavior, and his body shape [42]. Self-esteem and body dissatisfaction are considered predictors of ED and adolescence is a crucial phase for the positive or negative development of body image [14]. Predisposing factors related to ED also included sadness, anxiety, heart disease, diabetes and anemia. Eating behaviors begins to develop in childhood, by genetic determinants under family and social circle influences. Parental food choices are strongly linked to eating behavior of the children, influencing not only food choices, but also the ability to control what is ingested, as well as duration and frequency of meals [43].

BI distortion and BID can form a dangerous link between excessive concern with appearance and sudden and harmful changes in eating behavior, generating 
negative feelings and evaluation of one's own body, leading to ED [44]. Other factors, such as ethical or familiar factors, contribute to the development of this disordered eating behaviors [27]. In this sense, previous studies have established that the probability of developing a disordered eating attitude or a diagnosis of eating disorders is higher if the mother had a disordered eating or self-esteem problems $[32,33]$. Moreover, ethnicity has been linked to the perception of beauty ideals, selfesteem and body perception [27].

The literature shows that ED tends to be reported more commonly among female adolescents. Although the prevalence of ED found in the adolescent population can be masked due to their low rates of self-identification and help-seeking [45], in our study, the prevalence of ED symptoms was higher in girls (68.8\%) compared to boys (40.3\%). Typically, ED symptoms start among adolescents aged 14 to 17 years [46], being a warning sign for the adoption of habits considered unhealthy, such as smoking, use of illicit drugs, and self-mutilation in adulthood [47]. Previous studies $[24,47,48]$ have found a relationship between ED symptoms in adolescence and illicit drug use in adulthood. Raffoul et al. (2018) [49] found that strict dieting at age 14 was a predictor for smoking among adolescents and that each ED symptom at age 16 increased the odds of drug use by $27 \%$ at age 21 .

In some studies, the development of ED in boys and girls is reinforced by BID [39], corroborating the findings of previous studies [50,51]. Fortes et al. [51] showed that BID accounts for $51 \%$ of the variance of ED. In another study, Fortes et al. [50] showed that BID accounts for $59 \%$ of the variance in girls and $47 \%$ in boys; these values are rather higher than those found in our study, of $43.4 \%$ for girls and $34.7 \%$ for boys. The higher percentage found for girls may be due to the fact that they have internalized the 'thin ideal' more strongly than boys [52].

The results of this study allow reflections on the factors related to BID in adolescents of both sexes, a fact closely linked to the development of ED. However, it is known that the onset of both BID and ED symptoms has a multifactorial context. Therefore, parents and the school community must contribute to the development of a support network that encourages adolescents to develop a critical sense regarding the information disseminated by the media, as well as to their life choices, whether they are eating or practicing healthy habits.

In this sense, it reinforces the need for health professionals to be aware that disordered eating behaviors and BID may be present in adolescents, regardless of weight status, because although manifestations of these phenomena are relatively common among overweight adolescents, the same can manifest in subjects with weight considered adequate.

Although the results are of great interest to the health area, some limitations, such as the impossibility of establishing a causal link between the variables and the fact that this is a cross-sectional study, can be attributed to this research. To overcome these limitations, different forms of statistical analysis were employed to obtain consistent results. 


\section{Conclusions}

Main contribution of this study is the identification of eating disorder symptoms that can impact the health of adolescents, a population with a high prevalence of unhealthy eating habits and body image dissatisfaction. The close relationship between ED and BID has been the target of investigation among the adolescent population, and it is urgent to state that the concern of health professionals with this type of behavior is justified in view of the increased incidence of cases of this nature, which is not limited to a certain age group, socioeconomic status, or educational level.

Eating behavior is associated with adolescent's manner notices his own body makes the situation more complex regarding its resolution. Thus, encouraging the search for situations that bring satisfaction, resilience, and behavioral flexibility is necessary for the maturation of the controversial feelings characteristic of adolescence. Encouraging these conditions is essential for young people to become successful adults who are less affected by conditions such as those investigated in this study.

Author Contributions: Conceptualization, R.G.D., R.R.R. and R.H.; methodology, R.R.R and R.H; formal analysis, R.G.D.; investigation, R.R.R.; writing - original draft preparation, R.G.D.; writingreview and editing, R.H.; supervision, R.H.; project administration, R.G.D. and R.H. All authors have read and agreed to the published version of the manuscript.

Funding: This research received no external funding.

Institutional Review Board Statement: The study was conducted according to the guidelines of the Declaration of Helsinki, and approved by the Institutional Review Board (or Ethics Committee) of Federal University of Health Sciences of Porto Alegre (protocol code 741/11, date of approval 17.03.2011).

Informed Consent Statement: Informed consent was obtained from all subjects involved in the study.

Data Availability Statement: The data presented in this study are available on request from the corresponding author. The data are not publicly available due to ethical restrictions.

Acknowledgments: We would to like to thank the Postgraduate Program in Health Sciences from Federal University of Health Sciences of Porto Alegre and Education Department from Caxias do Sul.

Conflicts of Interest: The authors declare no conflict of interest.

\section{References}

1. CDC - CENTER FOR DISEASE CONTROL. Adolescence: Preparing for lifelong health and wellness [Internet].2018, [Cited 22 May 2019]. Available from: Centers for Disease Control and Prevention https://www.cdc.gov/grandrounds/pp/2015/20150818-adolescent-wellness.html

2. OPAS - ORGANIZAÇÃO PAN-AMERICANA DA SAÚDE. Ação global acelerada para a saúde de adolescentes (AA-HA!): guia de orientação para apoiar a implementação pelos países. 2018, Washington (DC). [Cited 18 Jun 2018]. Available from: https://iris.paho.org/handle/10665.2/49095. DOI: http://doi.org/10.37774/9789275719985. 
3. LAWLER, M,; NIXON. E. Body dissatisfaction among adolescents boys and girls: the effects of body mass, peer appearance culture and internalization of appearance ideals. J Youth Adolesc . 2011, 40(1):59-71. DOI: http://doi.org/10.1007/s10964-0099500-2.

4. LEE, J.; LEE, Y. The association of body image distortion with weight control behaviors, diet behaviors, physical activity, sadness, and suicidal ideation among Korean high school students: a cross-sectional study. BCM Public Health. 2016, 16:39. DOI: http://doi.org/10.1186/s12889-016-2703-z.

5. RODGERS, R.F.; PAXTON, S.J.; MCLEAN, S,A. A biopsychosocial model of body image concerns and disordered eating in early adolescents girls. J Youth Adolesc. 2014, 43(5):814-823. DOI: http://doi.org/10.1007/s10964-013-0013-7.

6. FELDEN, E. P. G.; CLAUMANN, G. S.; SACOMORI, C.; DARONCO, L. S. E.; CARDOSO, F. L.; PELEGRINI, A. Fatores sociodemográficos e imagem corporal em adolescentes do ensino médio. Cienc. saúde coletiva. 2015, 20(11):3329-3337. DOI: http://doi.org/10.1590/1413-812320152011.00212015.

7. MIRANDA, V.P.N.; AMARAL, A.C.S. FORTES, L.S.; CONTI, M.A.; FERREIRA, M.E.C. Estudo transversal sobre imagem corporal de adolescentes. Psicol Teor Prát. 2013,15(3):151-62.

8. GROGAN, S. Body Image: Understanding Body Dissatisfaction in Men, Women and Children, 3rd ed.; Routledge/Taylor \& Francis Group: London, UK; New York, NY, USA, 2017.

9. JONES, D.C.; NEWMAN, J.B. Early adolescent adjustment and critical evaluations by self and other: the prospective impact of body image dissatisfaction and peer appearance teasing on global self-esteem. Eur J Dev Sci. 2009, 3(1):17-26. DOI: http://doi.org/10.3233/DEV-2009-3104.

10. ROSENSTRÖM, T.; JOKELA, M.; HINTSANEN, M.; JOSEFSSON, K.; JUONALA, M.; KIVIMÄKI, M.; PULKKI-RABACK, L.; VIIKARI, J.; HUTRI-KÄHÖNEN, N.; HEINONEN, E.; RAITAKARI, O.T.; KELTIKANGAS-JÄRVINEN, L. Bodyimage dissatisfaction is strongly associated with chronic dysphoria. J Affect Disord. 2013, 150(2):253-260. DOI: http://doi.org/10.1016/j.jad.2013.04.003.

11. LADEIRA, T.F.; COPPUS, A.N.S. Anorexia e adolescência: uma articulação à luz da psicanálise. Reverso. 2016;38(71):75-82.

12. NASEM - NATIONAL ACADEMIES OF SCIENCES, ENGINEERING AND MEDICINE. The promise of adolescence: realizing opportunity for all youth. 2019, Washington (DC): The National Academies Press. 492p. DOI: http://doi.org./10.17226/25388

13. BANFIELD, E. C.; LIU, Y.; DAVIS, J. S.; CHANG, S.; FRAZIER-WOOD, A. C. Poor adherence to US dietary guidelines for children and adolescents in the national health and nutrition examination survey population. Journal of the Academy of Nutrition and Dietetics. 2016, 116 (January (1)), 21-27. DOI: http://doi.org/ 10.1016/j.jand.2015.08.010.

14. VOELKER, D.K.; REEL, J.J.; GREENLEAF, C. Weight status and body image perceptions in adolescents: Current perspectives. Adolesc. Health Med. 2015, 25, 149-158. DOI: http://doi.org/ 10.2147/AHMT.S68344

15. STEPHEN, E.M.; ROSE, J.S.; KENNEY, L. Prevalence and correlates of unhealthy weight control behaviors: Findings from the national longitudinal study of adolescent health. J. Eat. Disord. 2014, 2. DOI: http://doi.org/10.1186/2050-2974-2-16.

16. RECH, R. R. Prevalence of Obesity, Overweight and Eating Disorders in School-Based Population in Southern Brazil. Journal of Biosafety \& Health Education. 2013. v.01, p1-6. DOI: http://doi.org/10.4172/2332-0893.1000111

17. TIGGEMANN, M.; WILSON-BARRET, E. Children's figure ratings: relationship to self-steem and negative stereotyping. International Journal of Eating Disorders. 1998, v.23, n.3, p.83-88. DOI: http://doi.org/10.1002/(sici)1098108x(199801)23:1<83:aid-eat10>3.0.co;2-o.

18. CONDE, W.L.; MONTEIRO, C.A. Body mass index cutoff points for evaluation of nutritional status in Brazilian children and adolescents. J Pediat. 2006,82(4):266-72. DOI: http://doi.org/ 10.2223/JPED.1502.

19. BIGHETTI, F.; SANTOS, C.B.; SANTOS, J.E.; RIBEIRO, R.P.P. Tradução e validação do Eating Attitudes Test em adolescentes do sexo feminino de Ribeirão Preto, São Paulo. J. bras. Psiquiatr. 2004, 53(6): 339-346. DOI: http://doi.org/10.11606/D.22.2003.tde-12042004-234230. 
20. DE MICHELI, D.; ANDRADE, A.L.M.; DA SILVA, E.A.; FORMIGONI, M.L.O.S. (Eds). Neurociências do Abuso de Drogas na Adolescência: o que sabemos? São Paulo: Atheneu, 2014: pp.135-136.

21. FINATO, S.; RECH, R.R.; MIGON, P. Insatisfação com a imagem corporal em escolares do sexto ano da rede municipal de Caxias do Sul, no Rio Grande do Sul. Rev Paul Pediatr. 2013;31(1):65-70. DOI: https://doi.org/10.1590/S010305822013000100011.

22. CECON, R.S.; FRANCESCHINI, S.C.C.; PELUZIO, M.C.G.; HERMSDORFF, H.H.M.; PIORE, S.E. Overweight and Body Image Perception in Adolescents with Triage of Eating Disorders. The Scientific World Journal, 2017, v27, p1-6. DOI: https://doi.org/10.1155/2017/8257329

23. CHEAH, W. L.; HAZMI, H.; CHANG, C. T. Disordered eating and body image issues and their associated factors among adolescents in urban secondary schools in Sarawak, Malaysia. International Journal of Adolescent Medicine and Health. 2017, 1;29(2). DOI: https://doi.org/10.1515/ijamh-2015-0044.

24. MICALI, N.; SOLMI, F.; HORTON, N.J.; CROSBY, R.D.; EDDY, K.T.; CALZO, J.P.; SONNEVILLE, K.R.; SWANSON, S.A.; FIELD, A.E. Adolescent eating disorders predict psychiatric, high-risk behaviors and weight outcomes in young adulthood. J. Am. Acad. Child Adolesc. Psychiatry.2015, 54 (8), 652-659. DOI: https://doi.org/10.1016/j.jaac.2015.05.009

25. GOMES, A.P.F.; SOUZA, N.S.; VIDAL, S.L.; CASTANHEIRA, M. Fatores Antropométricos Relacionados à Insatisfação com a Imagem Corporal em Adolescentes. Rev. Baiana Saúde Pública. 2018, v.42, n.3, p.515-527. DOI: https://doi.org/10.22278/23182660.2018.v42.n3.a2815.

26. DEL DUCA, G.F.; GARCIA, L.M.; SOUSA, T.F.; OLIVEIRA, E.S.; NAHAS, M.V. Body weight dissatisfaction and associated factors among adolescents. Rev Paul Pediatr. 2010, 28:340-6. DOI: https://doi.org/10.1590/S0103-05822010000400009

27. DANTAS, R.P.N.C.; SIMÕES, T.B.S.; SANTOS, P.G.M.D.; DANTAS, P.M.S.; CABRAL, B.G.A.T. Satisfação da imagem corporal em adolescentes com diferentes estágios de maturação. J.Hum Growth Dev. 2017, 27(3):300-306. DOI: http://dx.doi.org/10.7322/jhgd.127574.

28. STEARNS, J.A.; CARSON, V.; SPENCE, J.C. The role of peer victimization in the physical activity and screen time of adolescents: a cross-sectional study. BMC Pediatrics. 2017, 17(1):170. DOI: https://doi.org/10.1186/s12887-017-0913-x.

29. UCHÔA, F.N.M.; UCHÔA, N.M.; DANIELE, T.M.D.C.; LUSTOSA, R.P.; GARRIDO, N.D.; DEANA, N.F.; ARANHA, A.C.M.; ALVES, N. Influence of the Mass Media and Body Dissatisfaction on the Risk in Adolescents of Developing Eating Disorders. Int J Environ Res Public Health. 2019, Apr 29;16(9):1508. DOI: https://doi.org/10.3390/ijerph16091508.

30. CECON, R. S.; FRANCESCHINI, S. C. C.; PELUZIO, M. C. G.; HERMSDORFF, H. H. M.; PRIORE, S. E. Overweight and Body Image Perception in Adolescents with Triage of Eating Disorders. The Scientific World Journal, 2017, 1-6. DOI: https://10.1155/2017/8257329

31. ALVES, T.C.H.S.; SANTANA, M. L P.; SILVA, R.C.R.; PINTO, E. J.; ASSIS, A. M. O. Fatores associados a sintomas de transtornos alimentares entre escolares da rede pública da cidade do Salvador, Bahia. J Bras Psiquiatr. 2012,61(2):55-63.

32. SOE, K.; HOLLAND, P.; MATEUS, C. Association Between Maternal Education and Childhood Mortalities in Myanmar. Asia Pac J Public Health. 2019, Nov;31(8):689-700. DOI: https://doi.org/10.1177/1010539519888299.

33. BOCCOLINI, C.S.; CARVALHO, M.L.; OLIVEIRA, M.I.C. Factors associated with exclusive breastfeeding in the first six months of life in Brazil: a systematic review. Revista de Saúde Pública. 2015, 49(91). DOI: https://doi.org/10.1590/S00348910.2015049005971.

34. PONS, M.; BENNASAR-VENY, M.; YAÑEZ, A.M. Maternal Education Level and Excessive Recreational Screen Time in Children: A Mediation Analysis. Int J Environ Res Public Health. 2020, Dec 1;17(23):8930. DOI: https://doi.org/10.3390/ijerph17238930

35. AMARAL, A. C. S.; FERREIRA, M.E.C Body dissatisfaction and associated factors among Brazilian adolescents: A longitudinal study. Body Image. 2017, 22, 32-38. DOI: https://10.1016/j.bodyim.2017.04.006 
36. THOMPSON, J.K.; STICE, E. Thin-Ideal internalization: Mounting evidence for a new risk factor for body-image disturbance and eating pathology. Curr. Dir. Psychol. Sci. 2001, 10, 181-183. DOI: https://doi.org/10.1111/1467-8721.00144

37. LEWER, M.; BAUER, A.; HARTMANN, A.S.; VOCKS, S. Different Facets of Body Image Disturbance in Binge Eating Disorder: A Review. Nutrients. 2017, Nov 28;9(12):1294. DOI: http://doi.org/10.3390/nu9121294.

38. RODIN, J.; SILBERSTEIN, L.; STRIEGEL-MOORE, R. (1984). Women and weight: A normative discontent. Nebraska Symposium on Motivation, 32, pp. 267-307.

39. MORAIS, N.S.; MIRANDA, V.P.N.; PRIORE, S.E. Imagem corporal de adolescentes do sexo feminino e sua associação à composição corporal e ao comportamento sedentário. Ciênc Saúde Colet. 2018, 23(8):2693-703. DOI: https://doi.org/10.1590/1413-81232018238.12472016

40. FLORÊNCIO, R.S.; MOREIRA, T.M.M.; SILVA, M.R.F.; ALMEIDA, I.L.S. Excesso ponderal em adultos jovens escolares: a vulnerabilidade da autopercepção corporal distorcida. Rev Bras Enferm. 2016, 69(2):258-65.

41. CAVAlCANTI, A. M. T. S.; ARRUDA, I. K. G.; LIMA, E. A. C. M.; NETO, W. B.; MONTEIRO, E.M.L.M.; LIMA, L. S.; DINIZ, A. S. Characterization of eating behavior disorders in school-aged children and adolescents: a population-based study. International Journal of Adolescent Medicine and Health. 2016, v.29, n.3, pp.1-8. DOI: https://doi.org/10.1515/ijamh-2015-0087.

42. LOFRANO-PRADO, M.C.; PRADO, W.L.; DE PIANO, A.; DAMASO, A.R. Obesidade e transtornos alimentares: a coexistência de comportamentos alimentares extremos em adolescentes. ConScientiae Saude. 2011, v10, n3, pp. 579-585. DOI: https://doi.org/10.5585/ConsSaude.v10i3.2559.

43. VIANA, V.; CANDEIAS, L.; REGO, C.; SILVA, D. Comportamento alimentar em crianças e controlo parental: uma revisão da bibliografia. Revista da Spcna. 2009, 15(1), 09-16.

44. FATT, S. J.; MOND, J.; BUSSEY, K.; GRIFFITHS, S.; MURRAY, S. B.; LONERGAN, A.; MITCHISON, D. Help-seeking for body image problems among adolescents with eating disorders: Findings from the EveryBODY study. Eat Weight Disord. 2019, 25, 1267-1275. DOI: https://doi.org/10.1007/s40519-019-00759-9

45. BRATLAND-SANDA, S.; SUNDGOT-BORGEN, J. Eating disorders in athletes: overview of prevalence, risk factors and recommendations for prevention and treatment. Eur J Sport Sci. 2013, 13(5):499-508. DOI: https://doi.org/10.1080/17461391.2012.740504

46. BORNIOLI, A.; LEWIS-SMITH, H.; SMITH, A.; SLATER, A.; BRAY, I. Adolescent body dissatisfaction and disordered eating: Predictors of later risky health behaviors. Soc Sci Med. 2019, 238:112458. DOI: https://doi.org/10.1016/j.socscimed.2019.112458

47. MICALI, N.; HORTON, N.J.; CROSBY, R.D.; SWANSON, S.A.; SONNEVILLE, K.R.; SOLMI, F.; CALZO, J.P.; EDDY, K.T.; FIELD, A.E. Eating disorder behaviors amongst adolescents: investigating classification, persistence and prospective associations with adverse outcomes using latent class models. Eur. Child Adolesc. Psychiatry 2017, 26 (2), 231-240. DOI: https://doi.org/ 10.1007/s00787-016-0877-7.

48. SONNEVILLE K.R.; HORTON, N.J.; MICALI, N.; CROSBY RD, SWANSON SA, SOLMI F, FIELD AE. Longitudinal associations between binge eating and overeating and adverse outcomes among adolescents and young adults: does loss of control matter? JAMA Pediatr 2013, Feb;167(2):149-55. DOI: https://doi.org/10.1001/2013.jamapediatrics.12.

49. RAFFOUL, A.; LEATHERDALE, S.T.; KIRKPATRICK, S.I. Dieting predicts engagement in multiple risky behaviors among adolescent Canadian girls: a longitudinal analysis. Can. J. Public Health 2018, 109 (1), 61-69. DOI: https://doi.org/10.17269/s41997-018-0025-x.

50. FORTES, L.S.; AMARAL, A.C.S.; ALMEIDA, S.S.; FERREIRA, M.E.C. Effects of pshychological, morphological and sociodemographic variables on adolescents eating behavior. Rev. Paul. Pediatr. 2013, 31, 182-188. DOI: https://doi.org/10.1590/S0103-05822013000200008 
51. FORTES, L.S.; MEIRELES, J.F.F.; NEVES, C.M.; ALMEIDA, S.S.; FERREIRA, M.E.C. Disordered eating, body dissatisfaction, perfectionism, and mood state in female adolescents. Rev. Nutr. 2015, 28, 371-383. DOI: https://doi.org/10.1590/1415$\underline{52732015000400004}$

52. MIRANDA, V.P.N.; CONTI, M.A.; BASTOS, R.; FERREIRA, M.E.C. Body dissatisfaction in Brazilian adolescents from small municipalities of Minas Gerais. J. Bras. Psiquiatr. 2011, 60, 190-197. DOI: https://doi.org/10.1590/S0047-20852011000300007 